\title{
Az agrotechnikai tényezók hatása a kukorica agronómiai tulajdonságaira tartamkísérletben
}

\author{
VÁRI ENIKÔ-PEPÓ PÉTER \\ Debreceni Egyetem AGTC Növénytudományi Intézet, Debrecen
}

\section{Összefoglalás}

Tartamkísérletben, csernozjom talajon, a Hajdúságban vizsgáltuk, hogy adott tószám (60 ezer/ha) esetén a különbözô tápanyagszintek hatására, valamint, hogy adott trágyaszint mellett $\left(\mathrm{N}_{120} \mathrm{P}_{90} \mathrm{~K}_{90}\right)$ a különböző tôszámok hatására hogyan változik a kukorica növények magassága, az üszögfertôzés, a csőfuzárium- fertőzés, a szárdôlés, valamint a Push-teszt értéke és a termés nagysága.

Vizsgálataink a 2010. év adatait tartalmazzák. Vetésváltás esetén három modell került beállításra (mono-, bi- [búza, kukorica], trikultúra [borsó, búza, kukorica]). A kezelésekben öt tápanyagszintet (kontroll [kezeletlen], $\mathrm{N}_{60} \mathrm{P}_{45} \mathrm{~K}_{45}, \mathrm{~N}_{120} \mathrm{P}_{90} \mathrm{~K}_{90}, \mathrm{~N}_{180} \mathrm{P}_{135} \mathrm{~K}_{135}$, $\mathrm{N}_{240} \mathrm{P}_{180} \mathrm{~K}_{180}$ ) és három állománysúrúségi értéket alkalmaztunk (40 ezer/ha, 60 ezer/ha, 80 ezer/ha).

A növekvő trágyaadagok hatására $\mathrm{N}_{240}+\mathrm{PK}$ tápanyagszintig szignifikánsan nőtt a növénymagasság, $\mathrm{N}_{240} \mathrm{P}_{180} \mathrm{~K}_{180}$ tápanyagszinten vetésváltástól függően 247,0-286,4 cm közötti értékeket mértünk. A különböző tápanyagszintek befolyásolták az üszög- és a csőfuzárium-fertőzés, a szárdőlés és a Push-teszt nagyságát. A legnagyobb értékeket mindhárom vetésváltási modellnél a $\mathrm{N}_{240}+\mathrm{PK}$ trágyaszinten kaptuk. A vetésváltás módosította az optimális trágyaadagot. Monokultúrás termesztés esetén a legnagyobb termést a $\mathrm{N}_{240}+\mathrm{PK}$ trágyaszintnél ( $8726 \mathrm{~kg} / \mathrm{ha}$ ), bikultúrában a $\mathrm{N}_{180}+\mathrm{PK}$ tápanyagszintnél (9371 kg/ha), míg a vetésváltás kedvezô hatása következményeként trikultúrában a $\mathrm{N}_{120}+$ PK trágyaszintnél értük el (9424 kg/ha).

A három vetésváltási rendszerben adott trágyaszint mellett $\left(\mathrm{N}_{120} \mathrm{P}_{90} \mathrm{~K}_{90}\right)$ a növényszám növelésének hatására szignifikánsan nem változtak az agronómiai és növényegészségügyi paraméterek. A tôszám növelésének hatására emelkedett a termés. A 
legnagyobb termésmennyiséget a 80 ezer/ha tőszám esetén tapasztaltuk (monokultúrában $7937 \mathrm{~kg} / \mathrm{ha}$, bikultúrában $9290 \mathrm{~kg} / \mathrm{ha}$, trikultúrában 9510 kg/ha). Mindhárom vetésváltás esetén érvényesült, hogy 60 ezer/ha állománysûrúségig a terméseredmények szignifikáns mértékben növekedtek, a 80 ezer/ha tőszám esetén már nem tapasztaltunk szignifikáns mértékú termésnövekedést.

A tôszám egyik vetésváltási modell esetén sem mutatott összefüggést egyik agronómiai tulajdonsággal sem. Ezzel szemben mindhárom vetésváltás esetén a trágyázás erôs vagy közepes pozitív kapcsolatot adott a kukorica növények magasságával $(0,928$ 0,967), az üszögfertôzés (0,734-0,795), a csőfuzárium-fertôzés $(0,658-0,817)$, és a szárdőlés $(0,752-0,825)$ mértékével, valamint a Push-teszt $(0,728-0,867)$ értékével és a termés nagyságával $(0,545-0,898)$.

Kulcsszavak: kukorica, vetésforgó, mútrágyázás, termés, agronómiai jellemzôk

\title{
The effect of agrotechnical factors on the agronomic features of maize in a long-term experiment
}

\author{
E. VÁRI-P. PEPÓ \\ University of Debrecen, Centre of Agricultural and Applied Economic Sciences, \\ Institute of Crop Sciences, Debrecen
}

\begin{abstract}
Summary
In a long-term field trial on chernozem soil in the Hajdúság region, the following two aspects were analysed: 1 ) the effect of different fertilisation levels at a specific crop density level ( 60 thousand $\mathrm{ha}^{-1}$ ) and 2) the effect of different crop density levels at a specific fertilisation level $\left(\mathrm{N}_{120} \mathrm{P}_{90} \mathrm{~K}_{90}\right)$ on the following parameters: plant height, corn smut infection, fusarium infection, lodging, Push-test and crop yield.

Data of the year 2010 were analysed. Three crop rotation models were used (monoand biculture [wheat, maize], triculture [pea, wheat, maize]). Five fertilisation levels (control [untreated], $\mathrm{N}_{60} \mathrm{P}_{45} \mathrm{~K}_{45}, \mathrm{~N}_{120} \mathrm{P}_{90} \mathrm{~K}_{90}, \mathrm{~N}_{180} \mathrm{P}_{135} \mathrm{~K}_{135}, \mathrm{~N}_{240} \mathrm{P}_{180} \mathrm{~K}_{180}$ ) and three crop density levels were used ( 40 thousand ha-1, 60 thousand ha-1, 80 thousand ha-1).

The increasing fertiliser doses significantly increased plant height up to the level of $\mathrm{N}_{240}+\mathrm{PK}$; at $\mathrm{N}_{240} \mathrm{P}_{180} \mathrm{~K}_{180}$ crop density the plant height ranged between 247.0 and
\end{abstract}


$286.4 \mathrm{~cm}$ respectively of the crop rotation system. Fertilisation levels influenced corn smut infection, fusarium ear rot, lodging and Push-test values. The highest values were obtained with $\mathrm{N}_{240}+\mathrm{PK}$ fertilisation level in all three crop rotation systems. The crop rotation system influenced the optimal level of fertilisation. The highest yield was obtained with $\mathrm{N}_{240}+\mathrm{PK}\left(8726 \mathrm{~kg} \mathrm{ha}^{-1}\right), \mathrm{N}_{180}+\mathrm{PK}\left(9371 \mathrm{~kg} \mathrm{ha}^{-1}\right)$ and $\mathrm{N}_{120}+\mathrm{PK}\left(9424 \mathrm{~kg} \mathrm{ha}^{-1}\right)$ fertilisation levels in monoculture, biculture and triculture, respectively.

The higher crop densities caused no significant change in the agronomic and plant health parameters at the fertilisation level $\left(\mathrm{N}_{120} \mathrm{P}_{90} \mathrm{~K}_{90}\right)$ in the three crop rotation systems. At higher crop density levels, yields also increased. The highest yields were obtained at the 80 thousand ha ${ }^{-1}$ crop density level (in monoculture: $7937 \mathrm{~kg} \mathrm{ha}^{-1}$, in biculture: $9290 \mathrm{~kg} \mathrm{ha}^{-1}$, in triculture: $9510 \mathrm{~kg} \mathrm{ha}^{-1}$ ). Crop yields significantly increased up to 60 thousand ha ${ }^{-1}$ crop density level; however, no significant increase was observed at the 80 thousand $\mathrm{ha}^{-1}$ crop density level.

There was no correlation between crop density and agronomic features in either crop rotation model. On the contrary, in all three crop rotation models there was strong or medium correlation between fertilisation and plant height (0.928-0.967), rust infection (0.734-0.795), fusarium ear rot (0.658-0.817), and lodging (0.752-0.825), as well as Push test values (0.728-0.867) and crop yield (0.545-0.898).

Key words: corn, crop rotation, fertilisation, yield, agronomic traits

\section{Влияние агротехнических факторов на агрономические свойства кукурузы в продолжительном опыте}

\section{Э. ВАРИ-П. ПЕПО}

Институт Ботаники Центра Агро-Экономических Наук Дебреценского Университета, Дебрецен

\section{Резюме}

В продолжительном опыте на чернозёмной почве в Хайдушаге (Hajdúság) исследовали, что в случае данного числа стеблей (60 тыс/га)под влиянием различных уровней питательного вещества, а также, что при данном уровне удобрения $\left(\mathrm{N}_{120} \mathrm{P}_{90} \mathrm{~K}_{90}\right)$ под влиянием различного числа растений как изменяется высота растений кукуру- 
зы, заражение головнёй кукурузы, фузариозом початков, падение стеблей, а также показатель Пуш-теста (Push-test) и величину урожая.

Наши исследования содержат данные 2010 года. В случае севосмена установили три модели (моно-, би- [пшеница, кукуруза], трикультура [горох, пшеница, кукуруза]). В обработках применяли пять уровней питательного вещества (контроль [без обработки], $\left.\mathrm{N}_{60} \mathrm{P}_{45} \mathrm{~K}_{45}, \mathrm{~N}_{120} \mathrm{P}_{90} \mathrm{~K}_{90}, \mathrm{~N}_{180} \mathrm{P}_{135} \mathrm{~K}_{135}, \mathrm{~N}_{240} \mathrm{P}_{180} \mathrm{~K}_{180}\right)$ и три числа густоты насаждений (40 тыс/га, 60 тыс/га, 80 тыс/га).

Под влиянием растущих доз удобрения до уровня $\mathrm{N}_{240}+\mathrm{PK}$ значительно увеличилась высота растений, на уровне питательного вещества $\mathrm{N}_{240} \mathrm{P}_{180} \mathrm{~K}_{180} 0$ в зависимости от севосмена измерили величины 247,0-286,4 см. Различные уровни питательного вещества повлияли на величину зарашений головнёй и фузариозом початка,на падение стеблей и на величину Push-теста. Самые большие величины при всех трёх моделях севосмена получили на уровне питательного вещества $\mathrm{N}_{240}+$ PК. Севосмен изменил оптимальную дозу удобрений. В случае монокультурного выращивания самый большой урожай достигли при уровне удобрений $\mathrm{N}_{240}+\mathrm{PK}$ (8726 кг/га), в бикультуре при $\mathrm{N}_{180}+\mathrm{PK}$ уровне удобрений (9371 кг/га), и как следствие благоприятного действия севосмена в трикультуре достигли самый большой урожай при уровне удобрений $\mathrm{N}_{120}+\mathrm{PK}$ (9424 кг/га).

$\mathrm{B}$ трёх севосменных системах при данном уровне удобрения $\left(\mathrm{N}_{120} \mathrm{P}_{90} \mathrm{~K}_{90}\right)$ под влиянием увеличения числа растений значительно не изменились агрономические и санитарные параметры растений. Под влиянием роста числа стеблей увеличился урожай. Самое большое количество урожая обнаружили в случае числа растений 80 тыс/га (в монокультуре 7937 кг/га, в бикультуре 9290 кг/га, в трикультуре 9510 кг/га). Во всех трёх севосменах проявилось, что до густоты насаждения 60 тыс/га результаты урожаев в значительной мере росли, а в случае числа стеблей 80 тыс/га уже не обнаружили значительного увеличения урожая.

Число стеблей ни при любой модели севосмена не показало связь ни с одним агрономическим свойствоим. В отличии от этого в случае всех трёх севосменов внесение удобрений показало сильную или среднюю позитивную связь с высотой кукурузных растений $(0,928-0,967)$, с показателем заражения головнёй $(0,734$ $0,795)$, фузариозом початка $(0,658-0,817)$, и с величиной падения стеблей $(0,752-$ $0,825)$, а также с показателем Push-теста $(0,728-0,867)$ и с величиной урожая $(0,545-0,898)$.

Ключевые слова: кукуруза, севооборот, внесение искусственных удобрений, урожай, агрономические показатели 


\section{Bevezetés és irodalmi áttekintés}

A kukoricát Magyarországon több mint 1 millió hektáron termesztik, termésátlaga az évjárattól és a termesztés színvonalától függóen 4-7 t/ha között változik.

Pepó (2006) szerint az agrotechnikai elemek közül kiemelkedô jelentôsége van a vetésváltásnak. A kukorica a részleges monokultúrát eltúri ugyan, de a monokultúrában termesztett kukorica átlagos évjáratban 1,3 t/ha-ral, aszályos évjáratban pedig 3-4t/ha-ral kevesebb termést adott a vetésváltásban termesztetthez képest. Monokultúrában a legnagyobb terméskiesést a gombabetegségek okozzák (Kurowski és Adamiak 2007). Gyôrffy és Berzsenyi (1992) megállapították, hogy a szakszerú vetésváltás egy eredményes és költségtakarékos eszköz a károsítók elleni védekezésben.

A vetésváltás az optimális $\mathrm{N}$ adag $(+\mathrm{PK})$ nagyságát is befolyásolja. Trikultúrában az $\mathrm{N}_{113}+\mathrm{PK}$, bikultúrában az $\mathrm{N}_{147}+\mathrm{PK}$, monokultúrában az $\mathrm{N}_{187}+\mathrm{PK}$ $\mathrm{kg} / \mathrm{ha}$ adagok voltak optimálisak a kukoricahibridek átlagában (Pepó 2001).

A kukoricatermesztésben kiemelkedô jelentősége van a harmonikus NPK tápanyag visszapótlásnak (Nagy és Huzsvai 2005). Sárvári és Boros (2010) szerint egyre korszerúbb kukoricahibridek kerülnek a termesztésbe, amelyeknek a mútrágya-hasznosító képességük egyre jobb. Amíg az 1970-80-as években $180 \mathrm{~kg} / \mathrm{ha} \mathrm{N}$ jelentette az agroökológiai optimumot, addig napjainkban ez 120 $\mathrm{kg} / \mathrm{ha} \mathrm{N}$ hatóanyag. N hiány esetén kisebb és lassabb a szárazanyag felhalmozás és kisebb levelek fejlődnek (Debreczeni és Szlovák 1985). Nagy (2007) véleménye, hogy a szükséges tápanyagok hiánya vagy túlzott mennyisége egyaránt megzavarja a növény növekedését, fejlődést, ami morfológiai elváltozásokkal és a termés mennyiségi, minôségi leromlásával jár. Izsáki (2005) növényanalízis alapján 64 különböző trágyakezelést vizsgálva megállapította, hogy a levélben legnagyobb koncentrációban a N (3-5\%) van jelen, majd ezt követi a kálium és a foszfor. A levél nitrogéntartalmának növekedésével összefüggésben nagyobb szemtermés képződik.

A kukoricatermesztés sikerességét alapvetôen meghatározza a kórokozók és kártevốk elleni védekezés. Minden olyan kártétel, élettani elváltozás, amely a zöld, fotoszintetizáló vegetatív felületet csökkenti, potenciális terméscsökkentố tényezô. A Fusarium fajok jelentôsen csökkentik a kukorica terméseredményét és minôségét a gyökér-, csô-, szempenészesedéssel, korhadással (Pepó et al. 2006). A kukorica betegségei közül a Fusarium fajok előfordulása 
lehet kihatással jelentôs mértékben a terméseredményekre (Clements et al. 2003). A kukoricatermesztés hatékonyságát a Diabrotica virgifera virgifera által okozott szárdólés is veszélyezteti. Száraz évjáratban a Diabrotica virgifera virgifera nem okozott növénydôlést, optimális vízellátottságú évjáratban viszont monokultúrás termesztésben jelentôs megdőlés következett be (Pepó 2009).

A kukorica termését a tőszám is befolyásolja, Gyôrffy (1976) szerint a kukorica termésére ható tényezők közül (trágyázás, fajta, ápolás, növényszám, mélymúvelés) a növényszám 20\%-kal részesedik a termésnövekedésből. Berzsenyi és Dang (2006) vizsgálatai azt mutatják, hogy a növényszám növelésének hatására a csốtermés és a szemtermés nagyobb arányban csökkent, mint a növény vegetatív szerveinek tömege.

\section{Anyag és módszer}

A vizsgálatokat a Debreceni Egyetem AGTC Látóképi Kísérleti Telepén, 1983ban dr. Ruzsányi László professzor úr által beállított tartamkísérletben végeztük. A kísérleti telep Debrecentôl 15 km-re nyugati irányban fekszik, a Hajdúsági Löszháton. A terület talaja sík, kiegyenlített, talajgenetikailag a mészlepedékes csernozjom típusba tartozik. A kiindulási állapot vizsgálati adatai azt mutatják, hogy a terület talajfizikailag a vályog kategóriába sorolható, kémhatása közel semleges. Foszforellátottsága közepesnek, káliumellátottsága közepes-jónak tekinthetô (1. táblázat).

Vizsgálataink a 2010. év adatait tartalmazzák. Vetésváltásra három modell került beállításra:

- monokultúra,

- bikultúra (búza, kukorica),

- trikultúra (borsó, búza, kukorica).

A kezelésekben öt tápanyagszintet (2. táblázat) és három állománysúrúségi értéket alkalmaztunk. A három állománysúrúségi érték 40 ezer/ha, 60 ezer/ha, valamint 80 ezer/ha volt. A kísérleti parcellák véletlen blokk elrendezéssel, 4 ismétlésben lettek beállítva, a parcellaméret $9,2 \mathrm{~m} \times 5 \mathrm{~m}$. Az alkalmazott kukorica hibrid a Reseda (PR37M81) volt. 
1. táblázat. A kísérleti terület talajvizsgálati adatai

(Debrecen)

\begin{tabular}{|c|c|c|c|c|c|c|c|c|}
\hline \multirow{3}{*}{$\begin{array}{l}\text { Talaj- } \\
\text { réteg } \\
(\mathrm{cm}) \\
(1)\end{array}$} & \multirow{3}{*}{$\begin{array}{c}\mathrm{pH} \\
(\mathrm{KCl}) \\
(2)\end{array}$} & \multirow{3}{*}{$\begin{array}{l}\text { KA } \\
\text { (3) }\end{array}$} & \multirow{3}{*}{$\begin{array}{c}\mathrm{CaCO}_{3} \\
\% \\
(4)\end{array}$} & \multirow{3}{*}{$\begin{array}{c}\text { Humusz } \\
\% \\
\text { (5) }\end{array}$} & \multirow{3}{*}{$\begin{array}{c}\text { Össz. N } \\
\% \\
(6)\end{array}$} & \multirow{3}{*}{$\begin{array}{c}\mathrm{NO}_{3}+ \\
\mathrm{NO}_{2} \\
\mathrm{ppm} \\
(7)\end{array}$} & $\begin{array}{c}\mathrm{P}_{2} \mathrm{O}_{5} \\
(8)\end{array}$ & $\begin{array}{c}\mathrm{K}_{2} \mathrm{O} \\
(9)\end{array}$ \\
\hline & & & & & & & \multicolumn{2}{|c|}{ AL oldható } \\
\hline & & & & & & & ppm & ppm \\
\hline $0-25$ & 6,46 & 43,0 & 0 & 2,76 & 0,150 & 6,20 & 133,4 & 239,8 \\
\hline $25-50$ & 6,36 & 44,6 & 0 & 2,16 & 0,120 & 1,74 & 48,0 & 173,6 \\
\hline $50-75$ & 6,58 & 47,6 & 0 & 1,52 & 0,086 & 0,60 & 40,4 & 123,0 \\
\hline $75-100$ & 7,27 & 46,6 & 10,25 & 0,90 & 0,083 & 1,92 & 39,8 & 93,6 \\
\hline $100-130$ & 7,36 & 45,4 & 12,75 & 0,59 & 0,078 & 1,78 & 31,6 & 78,0 \\
\hline
\end{tabular}

Table 1. Experimental soil data (Debrecen). (1) Soil layers $(\mathrm{cm}),(2) \mathrm{pH}$ value, (3) Soil physical structure (AK), (4) $\mathrm{CaCO}_{3} \%$, (5) Humus content \%, (6) Total $\mathrm{N} \%$, (7) $\mathrm{NO}_{3}+\mathrm{NO}_{2} \mathrm{ppm}$, (8) AL soluble $\mathrm{P}_{2} \mathrm{O}_{5}$, (9) AL soluble $\mathrm{K}_{2} \mathrm{O}$.

2. táblázat. A kísérletben alkalmazott mütrágyakezelések

(Debrecen 2010)

\begin{tabular}{lrcc}
\hline \multicolumn{1}{c}{ Kezelések } & $\mathrm{N}$ & $\mathrm{P}_{2} \mathrm{O}_{5}$ & $\mathrm{~K}_{2} \mathrm{O}$ \\
\hline 1. kezelés $(\mathrm{kg} / \mathrm{ha})$ & 0 & 0 & 0 \\
2. kezelés $(\mathrm{kg} / \mathrm{ha})$ & 60 & 45 & 45 \\
3. kezelés $(\mathrm{kg} / \mathrm{ha})$ & 120 & 90 & 90 \\
4. kezelés $(\mathrm{kg} / \mathrm{ha})$ & 180 & 135 & 135 \\
5. kezelés $(\mathrm{kg} / \mathrm{ha})$ & 240 & 180 & 180 \\
\hline
\end{tabular}

Table 2. Applied fertiliser doses. (1) Treatments.

A meteorológiai tényezók alakulását 2010-ben az 3. táblázat tartalmazza. A kukorica eredményes termesztéséhez meleg, napfényes, megfeleló vízellátottságú idôjárás szükséges. A kukorica melegigénye mellett a vízigénye is jelentôs. Különösen fontos a májusi meleg, a júliusi és augusztusi csapadék mennyisége, mivel vízigénye a címerhányás és a csőképzés idején a legnagyobb. A 2010. tenyészév márciusi átlaghómérséklete $7,6^{\circ} \mathrm{C}$ volt (a sokévi átlag $5,0^{\circ} \mathrm{C}$ ), és 19,1 mm-rel kevesebb csapadék hullott a sokévi átlaghoz képest. Az áprilisban 
(83,9 mm) és májusban (111,4 mm) lehullott csapadék mennyisége lényegesen meghaladta a sokévi átlagot $(42,4 \mathrm{~mm}$, ill. 58,8 mm), amely kedvezó vízellátottsági feltételeket biztosított a kukorica kezdeti fejlődéséhez. Ezen hónapok átlaghőmérséklete is $\left(11,6^{\circ} \mathrm{C}\right.$, ill. $\left.16,6^{\circ} \mathrm{C}\right)$ kedvezett a vegetatív fejlódésnek, mivel az átlag felettiek voltak $\left(10,7^{\circ} \mathrm{C}\right.$, ill. 15,8 $\left.{ }^{\circ} \mathrm{C}\right)$. A csapadékos és átlagosnál melegebb idójárás folytatódott júniusban és júliusban is, amely tovább biztosította a kukorica megfelelő vízellátását, és zavartalan fejlődését. Augusztusban is az átlagot meghaladó mennyiségú csapadék hullott, amely kedvezó volt a szemtelítôdési folyamatokra. A húvös és csapadékos szeptember következtében hosszabb volt az érés, lassúbb volt a szemtermés vízleadása.

3. táblázat. A meteorológiai tényezók alakulása a kukorica vegetációs periódusában (havi csapadék, havi átlaghömérséklet)

(Debrecen 2010)

\begin{tabular}{|c|c|c|c|c|c|c|c|}
\hline \multirow{3}{*}{$\begin{array}{l}\text { Hónap } \\
\text { (1) }\end{array}$} & \multicolumn{3}{|c|}{$\begin{array}{c}\text { Csapadék (mm) } \\
\text { (2) }\end{array}$} & \multirow{3}{*}{$\begin{array}{l}\text { Hónap } \\
\text { (1) }\end{array}$} & \multicolumn{3}{|c|}{$\begin{array}{l}\text { Hômérséklet }\left({ }^{\circ} \mathrm{C}\right) \\
\text { (3) }\end{array}$} \\
\hline & 2010 & 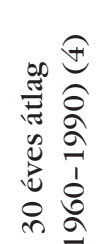 & 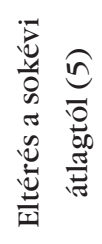 & & 2010 & 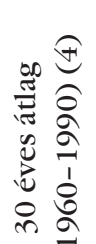 & 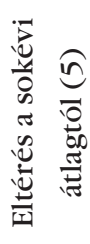 \\
\hline & & & 2010 & & & & 2010 \\
\hline Március (6) & 14,4 & 33,5 & $-19,1$ & Március (6) & 7,6 & 5,0 & 2,6 \\
\hline Április (7) & 83,9 & 42,4 & 41,5 & Április (7) & 11,6 & 10,7 & 0,9 \\
\hline Május (8) & 111,4 & 58,8 & 52,6 & Május (8) & 16,6 & 15,8 & 0,8 \\
\hline Június (9) & 100,9 & 79,5 & 21,4 & Június (9) & 19,7 & 18,7 & 1,0 \\
\hline Július (10) & 97,2 & 65,7 & 31,5 & Július (10) & 22,0 & 20,3 & 1,7 \\
\hline Augusztus (11) & 98,3 & 60,7 & 37,6 & Augusztus (11) & 19,0 & 19,6 & $-0,6$ \\
\hline Szeptember (12) & 98,4 & 38,0 & 60,4 & Szeptember (12) & 14,1 & 15,8 & $-1,7$ \\
\hline $\begin{array}{l}\text { Csapadék összesen } \\
(\mathrm{mm})(13)\end{array}$ & 630,5 & 378,6 & 251,9 & $\begin{array}{l}\text { Átlaghömérséklet } \\
\left({ }^{\circ} \mathrm{C}\right)(14)\end{array}$ & 15,8 & 15,1 & 0,7 \\
\hline
\end{tabular}

Table 3. Meteorological parameters in the vegetation period of maize (precipitation, mean monthly temperature, Debrecen, 2010). (1) Month, (2) Precipitation, (3) Temperature, (4) 30-year average, (5) Difference, (6) March, (7) April, (8) May, (9) June, (10) July, (11) August, (12) September, (13) Total rainfall, (14) Mean temperature. 
A kísérletben alkalmazott talajmúvelési eljárások és növényvédelmi kezelések elvégzésének időpontjait a 4. táblázat tartalmazza. A kukorica vetését mindhárom vetésváltási modellben azonos időpontban végeztük (2010. 04. 23.). A talajfertôtlenítést csak a monokultúrás termesztésnél alkalmaztuk, a vetéssel egy menetben. A kijuttatott talajfertőtlenítő szer a Force $1,5 \mathrm{G}$ volt, $14 \mathrm{~kg} / \mathrm{ha}$ os dózisban. A gyomok ellen mindhárom vetésváltásnál azonos időpontban (2010. 05. 26.), azonos szerkombinációval védekeztünk (Laudis [2,25 1/ha] +Banvel 480 [0,3 1/ha]). A parcellák betakarítását automata mérleggel felszerelt Sampo 2010 típusú parcella kombájn segítségével végeztük, amely Oros 2011 típusú kétsoros kukorica adapterrel van felszerelve.

4. táblázat. A kisérletben alkalmazott talajmüvelési eljárások és növényvédelmi kezelések

\begin{tabular}{lccc}
\hline \multicolumn{1}{c}{\begin{tabular}{c} 
Múveletek \\
\multicolumn{1}{c}{$(1)$}
\end{tabular}} & $\begin{array}{c}\text { Monokultúra } \\
(2)\end{array}$ & $\begin{array}{c}\text { Bikultúra } \\
(3)\end{array}$ & $\begin{array}{c}\text { Trikultúra } \\
(4)\end{array}$ \\
\hline Tarlóhántás (5) & - & 2009.07 .23 & 2009.07 .23 \\
Ôszi mútrágyaszórás (6) & 2009.10 .08 & 2009.08 .10 & 2009.08 .11 \\
Mútrágya bedolgozás (7) & 2009.10 .09 & 2009.08 .10 & 2009.08 .11 \\
Ószi szántás (8) & 2009.10 .19 & 2009.09 .29 & 2009.10 .19 \\
Szántás elmunkálás (9) & 2010.03 .23 & 2010.03 .23 & 2010.03 .23 \\
Tavaszi mútrágyaszórás (10) & 2010.04 .13 & 2010.04 .21 & 2010.04 .13 \\
Mútrágya bedolgozás (7) & 2010.04 .13 & 2010.04 .23 & 2010.04 .13 \\
Magágy-készítés (11) & 2010.04 .23 & 2010.04 .23 & 2010.04 .23 \\
Vetés (12) & 2010.04 .23 & 2010.04 .23 & 2010.04 .23 \\
Talajfertôtlenítés (13) & 2010.04 .23 & - & - \\
Gyomirtás (14) & 2010.05 .26 & 2010.05 .26 & 2010.05 .26 \\
Kultivátorozás (15) & 2010.06 .09 & 2010.06 .09 & 2010.06 .09 \\
Betakarítás (16) & 2010.10 .11 & 2010.10 .04 & 2010.10 .08 \\
\hline
\end{tabular}

Table 4. Applied soil cultivation and crop protection treatments. (1) Agrotechnical elements, (2) Monoculture, (3) Biculture, (4) Triculture, (5) Stubble, (6) Autumn fertilisation, (7) Incorporation of fertiliser, (8) Autumn ploughing, (9) Plough tillage, (10) Spring fertiliser, (11) Seed-bed preparation, (12) Sowing, (13) Soil disinfection, (14) Weed control, (15) Mechanical weed control, (16) Harvest. 


\section{Eredmények és értékelés}

Vizsgáltuk mindhárom vetésváltási rendszerben, hogy adott tôszám (60 ezer/ha) esetén a különbözó tápanyagszintek hatására hogyan változik a kukorica növények magassága, az üszögfertôzés, a csőfuzárium-fertőzés, és a szárdőlés mértéke, valamint a Push-teszt értéke és a termés nagysága (5. táblázat).

5. táblázat. A vetésváltás és a tápanyagellátás hatása a kukorica agronómiai tulajdonságaira

(Debrecen 2010)

\begin{tabular}{|c|c|c|c|c|c|c|c|}
\hline $\begin{array}{l}\text { Vetés- } \\
\text { váltás } \\
\text { (A) } \\
\text { (1) }\end{array}$ & $\begin{array}{l}\text { Tápanyag- } \\
\text { szint } \\
\text { (B) } \\
\text { (2) }\end{array}$ & $\begin{array}{l}\text { Növ. } \\
\text { mag. } \\
(\mathrm{cm}) \\
(3)\end{array}$ & $\begin{array}{c}\text { Üszög- } \\
\text { fert. } \\
(\%) \\
(4)\end{array}$ & $\begin{array}{c}\text { Cső- } \\
\text { fuzárium } \\
\text { (\%) } \\
\text { (5) }\end{array}$ & $\begin{array}{l}\text { Szár- } \\
\text { dőlés } \\
\text { (\%) } \\
\text { (6) }\end{array}$ & $\begin{array}{l}\text { Push- } \\
\text { teszt } \\
(\%) \\
(7)\end{array}$ & $\begin{array}{c}\text { Termés } \\
\text { (kg/ha) } \\
\text { (8) }\end{array}$ \\
\hline \multirow{5}{*}{$\begin{array}{l}60000 \\
\text { Mono- } \\
\text { kultúra } \\
\text { (9) }\end{array}$} & kontroll & 160,1 & 1,9 & 1,7 & 2,0 & 5,2 & 4639 \\
\hline & $\mathbf{N}_{60} \mathbf{P}_{45} \mathbf{K}_{45}$ & 185,8 & 2,6 & 2,7 & 4,7 & 8,1 & 6584 \\
\hline & $\mathbf{N}_{120} \mathbf{P}_{90} \mathbf{K}_{90}$ & 213,5 & 4,3 & 3,1 & 6,2 & 10,7 & 7719 \\
\hline & $\mathbf{N}_{180} \mathbf{P}_{135} \mathbf{K}_{135}$ & 235,2 & 4,8 & 4,3 & 6,9 & 12,0 & 7892 \\
\hline & $\mathbf{N}_{240} \mathbf{P}_{180} \mathbf{K}_{180}$ & 247,0 & 5,2 & 4,7 & 7,6 & 13,8 & 8726 \\
\hline 60000 & kontroll & 201,2 & 1,6 & 2,4 & 2,9 & 5,1 & 7840 \\
\hline $\mathrm{Bi}-$ & $\mathbf{N}_{60} \mathbf{P}_{45} \mathbf{K}_{45}$ & 228,6 & 1,9 & 2,7 & 3,7 & 6,2 & 8437 \\
\hline kultúra & $\mathbf{N}_{120} \mathbf{P}_{90} \mathbf{K}_{90}$ & 263,1 & 2,6 & 3,6 & 4,7 & 8,9 & 8907 \\
\hline (10) & $\mathbf{N}_{180} \mathbf{P}_{135} \mathbf{K}_{135}$ & 281,4 & 3,1 & 4,7 & 5,2 & 9,7 & 9371 \\
\hline & $\mathbf{N}_{240} \mathbf{P}_{180} \mathbf{K}_{180}$ & 286,3 & 3,5 & 5,3 & 5,9 & 10,4 & 9006 \\
\hline 60000 & kontroll & 219,6 & 1,9 & 2,0 & 4,2 & 7,6 & 6956 \\
\hline Tri- & $\mathbf{N}_{60} \mathbf{P}_{45} \mathbf{K}_{45}$ & 240,5 & 2,7 & 2,5 & 5,8 & 9,6 & 8482 \\
\hline kultúra & $\mathbf{N}_{120} \mathbf{P}_{90} \mathbf{K}_{90}$ & 259,4 & 3,6 & 2,9 & 8,3 & 11,9 & 9424 \\
\hline (11) & $\mathbf{N}_{180} \mathbf{P}_{135} \mathbf{K}_{135}$ & 270,1 & 4,2 & 3,6 & 8,6 & 13,5 & 9143 \\
\hline$(11)$ & $\mathbf{N}_{240} \mathbf{P}_{180} \mathbf{K}_{180}$ & 281,4 & 5,0 & 3,4 & 10,1 & 14,7 & 9242 \\
\hline $\mathrm{SzD}_{5 \%}(\mathrm{~A})$ & 12) & 11,6 & 1,3 & 1,1 & 2,1 & 3,8 & 641 \\
\hline $\mathrm{SzD}_{5 \%}(\mathrm{~B})$ & 13) & 7,1 & 0,8 & 0,7 & 1,1 & 1,5 & 390 \\
\hline $\mathrm{SzD}_{5 \%}(\mathrm{~A} \times$ & ) (14) & 12,2 & 1,3 & 1,2 & 1,8 & 2,7 & 676 \\
\hline
\end{tabular}

Table 5. The effects of crop rotation and fertiliser on agronomic characteristic of maize (Debrecen 2010). (1) Crop rotation, (2) Fertiliser doses, (3) Plant height (cm), (4) Corn smut infection, (\%),

(5) Infection of corn cob fusarium (\%), (6) Lodging (\%), (7) Push-test (\%), (8) Yield (kg ha-1),

(9) Monoculture, (10) Biculture, (11) Triculture, (12) $\mathrm{LSD}_{5 \%} \mathrm{~A}$, (13) $\mathrm{LSD}_{5 \%} \mathrm{~B}$, (14) $\mathrm{LSD}_{5 \%} \mathrm{~A} \times \mathrm{B}$. 
A Push-teszt érték megállapításánál parcellánként 10 növény szárára lábbal erôt fejtettünk ki. Amennyiben a kukorica $45^{\circ}$ vagy annál kisebb szöget zár be a talajjal a taposás után, akkor megdőltnek tekintettük. A megdőlt növények arányát \%-ban adtuk meg hektárra vonatkoztatva.

A tápanyagszintek növénymagasságra gyakorolt hatásánál az a tendencia érvényesült, hogy a növekvő trágyaadagok hatására $\mathrm{N}_{240}+\mathrm{PK}$ tápanyagszintig szignifikánsan nôtt a növénymagasság, vetésváltástól függően 247,0-286,4 cm közötti értékeket mértünk. A 2010. évben a kontroll parcellákban minimális volt az üszög- (1,6-1,9\%) és a fuzárium-fertőzés mértéke (1,7-2,4\%). mindhárom vetésváltás esetén. A nagyobb mútrágya adagok növelték a fertőzöttség mértékét, és a legmagasabb értéket a legnagyobb tápanyagszinten $\left(\mathrm{N}_{240}+\mathrm{PK}\right)$ kaptuk, üszögfertőzésnél monokultúrában 5,2\%-ot, bikultúrában 3,5\%-ot, trikultúrában 5,0\%-ot, míg csőfuzáriumnál 4,7\%, 5,3\% és 3,4\%-ot. Megállapítható, hogy a különböző tápanyagszintek befolyásolták a szárdőlés nagyságát is. A nem trágyázott parcellákban 2,0-4,2\% közötti, a legnagyobb trágyaszintnél pedig 5,1-10,1\% közötti értékeket állapítottunk meg. A Push-teszt során kapott eredmények is hasonló tendenciát mutatnak. A nagyobb mútrágyaadagok növelték a Push-teszt nagyságát, a legnagyobb értéket a trikultúrás termesztésben, a $\mathrm{N}_{240}+$ PK trágyaszinten kaptuk (14,7\%). Igen jelentős termésnövekedést lehetett megállapítani a tápanyagellátás hatására. A kontroll parcellákban vetésváltástól függốen 4939-7840 kg/ha közötti termésmennyiséget mértünk. Monokultúrában 4639-8726 kg/ha között, bikultúrában 7840-9371 kg/ha között, trikultúrás termesztésben 6956-9424 kg/ha között változott a kukorica termésmennyisége trágyaadagtól függôen. Monokultúrás termesztés esetén a legmagasabb termést a $\mathrm{N}_{240}+$ PK trágyaszintnél ( $8726 \mathrm{~kg} / \mathrm{ha}$ ), bikultúrában a $\mathrm{N}_{180}+$ PK tápanyagszintnél $(9371 \mathrm{~kg} / \mathrm{ha})$, míg a vetésváltás kedvezô hatása következményeként trikultúrában a $\mathrm{N}_{120}+\mathrm{PK}$ trágyaszintnél értük el $(9424 \mathrm{~kg} / \mathrm{ha})$.

A terméseredmények alapján regresszió analízissel kiszámítottuk a trágya optimum értékeket, amelyek a vetésváltás hatására jelentôsen változtak (1.ábra). Monokultúra esetén $240 \mathrm{~kg} \mathrm{~N}, 180 \mathrm{~kg} \mathrm{P}_{2} \mathrm{O}_{5}$ és $180 \mathrm{~kg} \mathrm{~K}_{2} \mathrm{O}$ volt a trágya optimum. Bikultúra esetén a legnagyobb termést alacsonyabb mútrágya értéknél tapasztaltuk ( $192 \mathrm{~kg} \mathrm{~N}, 144 \mathrm{~kg} \mathrm{P}_{2} \mathrm{O}_{5}$ és $144 \mathrm{~kg} \mathrm{~K} \mathrm{~K}_{2}$ ). Trikultúrában a termésmaximumhoz tartozó mútrágya adagok $174 \mathrm{~kg} \mathrm{~N}, 130,5 \mathrm{~kg} \mathrm{P}_{2} \mathrm{O}_{5}$ és $130,5 \mathrm{~kg}$ $\mathrm{K}_{2} \mathrm{O}$ volt. 
1. ábra. A tápanyagellátás hatása a kukorica termésére 60 ezer/ha tôszámnál különbözó vetésváltás esetén

(Debrecen 2010)

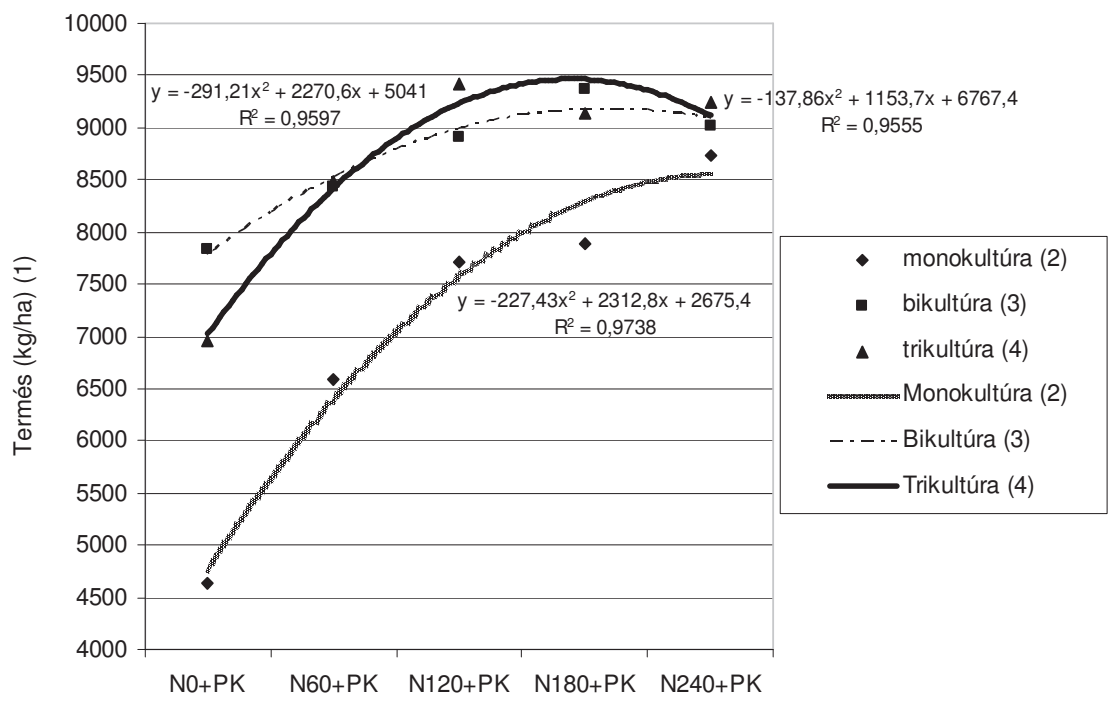

Figure 1. The effect of nutrient supply on maize yield at 60 thousand plants per hectare in various crop rotations (Debrecen 2010). (1) Yield ( $\left.\mathrm{kg} \mathrm{ha}^{-1}\right)$, (2) Monoculture, (3) Biculture, (4) Triculture.

Kerestük a választ arra is, hogy a három vetésváltási rendszerben adott trágyaszint mellett $\left(\mathrm{N}_{120} \mathrm{P}_{90} \mathrm{~K}_{90}\right)$ a különböző tôszámok hatására hogyan változtak az agronómiai és növény-egészségügyi paraméterek. Az adatokat a 6. táblázat tartalmazza.

A növényszám növelésének hatására szignifikánsan nem változott a növénymagasság. Monokultúrában 210,2-211,5 cm, bikultúrában 263,1-271,6 cm, trikultúra vetésváltás esetén 256,2-259,4 cm közötti növénymagasságokat mértünk. A tôszám nem befolyásolta jelentôsen az üszög- és a csôfuzárium-fertôzés mértékét. A három vetésváltásnál nagyon hasonló eredményeket kaptunk mindhárom állománysûrúség esetén (üszögfertőzés: 2,4-4,6\%, csôfuzáriumfertőzés: 2,5-3,9\%). A Push-teszt értékeket sem befolyásolta jelentôsen a tôszám, monokultúrában 10,4-11,2\%-ot, bikultúrában 8,2-9,1\%-ot, trikultúrás termesztés esetén pedig 11,2-11,9\%-ot tapasztaltunk. A tôszám növelésének hatására emelkedett a termés. Mindhárom vetésváltás esetén érvényesült, hogy 60 ezer/ha állománysûrúségig a terméseredmények szignifikáns mértékben 
növekedtek, monokultúrában $4087 \mathrm{~kg} / \mathrm{ha}$, bikultúrában $1531 \mathrm{~kg} / \mathrm{ha}$, trikultúrában $2468 \mathrm{~kg} /$ ha terméstöbbletet mértünk. 80 ezer/ha tôszám esetén már nem tapasztaltunk szignifikáns mértékú termésnövekedést. Pearson-féle korrelációszámítással meghatároztuk a 2010. tenyészévben a tôszám, a mútrágyaadagok nagysága, a növénymagasság, az üszög- és a csőfuzárium-fertőzés, a szárdőlés, a Push-teszt, és a termés mennyisége közötti kapcsolatrendszert eltérô vetésváltás esetén. Vizsgálatainkban a 0,5 alatti értékkel jellemezhetô korrelációt gyengének, a 0,5-0,7 közötti r értékeket közepesnek, míg a 0,7 feletti korrelációs együttható esetén a kapcsolatot szorosnak tekintjük.

6. táblázat. A vetésváltás és a tôszám hatása a kukorica

agronómiai tulajdonságaira

(Debrecen 2010)

\begin{tabular}{|c|c|c|c|c|c|c|c|c|}
\hline $\begin{array}{l}\text { Vetés- } \\
\text { váltás } \\
\text { (A) } \\
\text { (1) }\end{array}$ & $\begin{array}{c}\text { Tőszám } \\
\text { (B) } \\
\text { (2) }\end{array}$ & $\begin{array}{c}\text { Tápanyag- } \\
\text { szint } \\
\text { (3) }\end{array}$ & $\begin{array}{l}\text { Növ. } \\
\text { mag. } \\
(\mathrm{cm}) \\
(4)\end{array}$ & $\begin{array}{l}\text { Üszög- } \\
\text { fert. } \\
(\%) \\
(5)\end{array}$ & $\begin{array}{c}\text { Cső- } \\
\text { fuzárium } \\
(\%) \\
(6)\end{array}$ & $\begin{array}{c}\text { Szár- } \\
\text { dőlés } \\
(\%) \\
(7)\end{array}$ & $\begin{array}{l}\text { Push- } \\
\text { teszt } \\
(\%) \\
(8)\end{array}$ & $\begin{array}{c}\text { Termés } \\
\text { (kg/ha) } \\
\text { (9) }\end{array}$ \\
\hline Mono- & 40000 & $\mathbf{N}_{120} \mathbf{P}_{90} \mathbf{K}_{90}$ & 211,5 & 4,6 & 3,6 & 6,3 & 10,4 & 7176 \\
\hline kultúra & 60000 & & 213,5 & 4,3 & 3,1 & 6,2 & 10,7 & 7719 \\
\hline (10) & 80000 & & 210,2 & 3,8 & 3,4 & 6,5 & 11,2 & 7937 \\
\hline $\mathrm{Bi}-$ & 40000 & $\mathbf{N}_{120} \mathbf{P}_{90} \mathbf{K}_{90}$ & 268,6 & 2,9 & 3,9 & 4,6 & 8,2 & 8108 \\
\hline kultúra & 60000 & & 263,1 & 2,6 & 3,6 & 4,7 & 8,9 & 8907 \\
\hline (11) & 80000 & & 271,6 & 2,4 & 3,6 & 4,7 & 9,1 & 9290 \\
\hline Tri- & 40000 & $\mathbf{N}_{120} \mathbf{P}_{90} \mathbf{K}_{90}$ & 256,2 & 3,8 & 2,5 & 7,6 & 11,2 & 8685 \\
\hline kultúra & 60000 & & 259,4 & 3,6 & 2,9 & 8,3 & 11,9 & 9424 \\
\hline$(12)$ & 80000 & & 258,0 & 3,6 & 2,9 & 6,8 & 11,2 & 9510 \\
\hline \multicolumn{2}{|c|}{$\mathrm{SzD}_{5 \%}(\mathrm{~A})(13)$} & & 14,3 & 2,0 & 1,9 & 2,2 & 4,7 & 860 \\
\hline \multicolumn{2}{|c|}{$\mathrm{SzD}_{5 \%}(\mathrm{~B})(14)$} & & 7,0 & 0,7 & 0,7 & 1,1 & 1,6 & 368 \\
\hline \multicolumn{2}{|c|}{$\mathrm{SzD}_{5 \%}(\mathrm{~A} \times \mathrm{B})(15)$} & & 12,1 & 1,2 & 1,3 & 1,9 & 2,8 & 637 \\
\hline
\end{tabular}

Table 6. The effects of crop rotation and plant number on agronomic characteristic of maize (Debrecen 2010). (1) Crop rotation (A), (2) Plant number (B), (3) Fertiliser, (4) Plant height (cm), (5) Corn smut infection, (\%), (6) Infection of corn cob fusarium (\%), (7) Lodging (\%), (8) Pushtest (\%), (9) Yield (kg ha $\left.{ }^{-1}\right)$, (10) Monoculture, (11) Biculture, (12) Triculture, (13) LSD $_{5 \%}$ A, (14) $\mathrm{LSD}_{5 \%} \mathrm{~B},(15) \mathrm{LSD}_{5 \%} \mathrm{~A} \times \mathrm{B}$. 
A tôszám egyik vetésváltási modell esetén sem mutatott kapcsolatot, összefüggést egyik agronómiai tulajdonsággal sem. Mindhárom vetésváltás esetén szoros kapcsolatot állapítottunk meg a tápanyagszint és a növénymagasság között (7. táblázat).

\section{7. táblázat. Pearson-féle korreláció a vizsgált tényezók között mono-, bi-és trikultúrában}

(Debrecen 2010)

\begin{tabular}{|c|c|c|c|c|c|c|c|}
\hline & & $\begin{array}{l}\text { Növ. } \\
\text { mag. } \\
(1)\end{array}$ & $\begin{array}{l}\text { Üszög- } \\
\text { fert. } \\
(2) \\
\end{array}$ & $\begin{array}{c}\text { Cső- } \\
\text { fuzárium } \\
\text { (3) }\end{array}$ & $\begin{array}{l}\text { Szár- } \\
\text { dőlés } \\
(4)\end{array}$ & $\begin{array}{l}\text { Push- } \\
\text { teszt } \\
(5) \\
\end{array}$ & $\begin{array}{c}\text { Termés } \\
\text { (6) }\end{array}$ \\
\hline $\begin{array}{l}\text { Mono- } \\
\text { kultúra }\end{array}$ & Tôszám (8) & 0,001 & $-0,085$ & 0,013 & $-0,039$ & 0,009 & 0,185 \\
\hline (7) & Tápanyagszint (9) & $\begin{array}{c}0,967 \\
(* *)\end{array}$ & $\begin{array}{c}0,795 \\
(* *)\end{array}$ & $\begin{array}{c}0,737 \\
(* *)\end{array}$ & $\begin{array}{c}0,825 \\
(* *)\end{array}$ & $\begin{array}{c}0,867 \\
(* *)\end{array}$ & $\begin{array}{c}0,898 \\
(* *)\end{array}$ \\
\hline $\begin{array}{l}\text { Bi- } \\
\text { kultúra }\end{array}$ & Tőszám (8) & 0,024 & $-0,086$ & $-0,006$ & $-0,037$ & 0,066 & $\begin{array}{c}0,534 \\
(* *)\end{array}$ \\
\hline (10) & Tápanyagszint (9) & $\begin{array}{c}0,940 \\
(* *)\end{array}$ & $\begin{array}{c}0,734 \\
(* *)\end{array}$ & $\begin{array}{c}0,817 \\
(* *)\end{array}$ & $\begin{array}{c}0,764 \\
(* *)\end{array}$ & $\begin{array}{c}0,718 \\
(* *)\end{array}$ & $\begin{array}{c}0,545 \\
(* *)\end{array}$ \\
\hline $\begin{array}{l}\text { Tri- } \\
\text { kultúra }\end{array}$ & Tőszám (8) & 0,057 & $-0,049$ & 0,139 & $-0,123$ & 0,061 & $\begin{array}{c}0,369 \\
(* *)\end{array}$ \\
\hline (11) & Tápanyagszint (9) & $\begin{array}{c}0,928 \\
(* *)\end{array}$ & $\begin{array}{c}0,777 \\
(* *) \\
\end{array}$ & $\begin{array}{c}0,658 \\
(* *) \\
\end{array}$ & $\begin{array}{c}0,752 \\
(* *)\end{array}$ & $\begin{array}{c}0,743 \\
(* *) \\
\end{array}$ & $\begin{array}{c}0,649 \\
(* *) \\
\end{array}$ \\
\hline
\end{tabular}

Table 6. Correlation between the analysed parameters in the mono-, bi-, triculture (Debrecen 2010). (1) Plant height, (2) Corn smut infection, (3) Infection of corn cob fusarium, (4) Lodging, (5) Push-test, (6) Yield, (7) Monoculture, (8) Plant number, (9) Fertiliser, (10) Biculture, (11) Triculture.

A trágyázás és termés között monokultúra $(0,898)$ esetén szoros pozitív korrelációt, bi- $(0,545)$ és trikultúránál $(0,649)$ pedig közepes pozitív kapcsolatot mutatott az r érték alakulása. A búza után vetett kukoricánál csak közepes mértékú, pozitív összefüggés adódott a trágyázás és termés között, amely azzal hozható összefüggésbe, hogy az elôvvetemény a talaj tápanyagtartalmára kedvezóen hatott.

A nem egyoldalú tápanyagfelhasználás következtében a talajban lévô tápanyagok a kukorica igényét jól ki tudták elégíteni, így a trágyaadagok termésre gyakorolt hatása mérsékeltebb volt. A trikultúrás termesztésnél is a talaj tápa- 
nyagtartalmára kedvezô hatást gyakorolt az elôvetemény, emiatt kaptunk közepes, pozitív kapcsolatot. Összességében megállapítható, hogy a trágyázás termésre gyakorolt hatása tekintetében a legszorosabb pozitív korrelációt a monokultúrás termesztés során kaptuk.

\section{Következtetések}

A növekvő trágyaadagok hatására $\mathrm{N}_{240}+\mathrm{PK}$ tápanyagszintig szignifikánsan nôtt a növénymagasság. A különböző tápanyagszintek befolyásolták az üszög- és a csőfuzárium- fertőzés, a szárdőlés és a Push-teszt nagyságát, a legnagyobb értéket mindhárom vetésváltási modellnél a $\mathrm{N}_{240}+\mathrm{PK}$ trágyaszinten kaptuk. Igen jelentôs termésnövekedést állapítottunk meg a tápanyagellátás hatására. Monokultúrás termesztés esetén a legmagasabb termést a $\mathrm{N}_{240}+\mathrm{PK}$ trágyaszintnél, bikultúrában a $\mathrm{N}_{180}+\mathrm{PK}$ tápanyagszintnél, míg a vetésváltás kedvező hatása következményeként trikultúrában a $\mathrm{N}_{120}+\mathrm{PK}$ trágyaszintnél értük el.

A három vetésváltási rendszerben adott trágyaszint mellett $\left(\mathrm{N}_{120} \mathrm{P}_{90} \mathrm{~K}_{90}\right)$ a különböző tôszámok hatására változtak a vizsgált agronómiai tulajdonságok. A növényszám növelésének hatására szignifikánsan nem változott a növénymagasság, az üszög- és a csôfuzárium-fertőzés, a szárdőlés, a Push-teszt értéke. Mindhárom vetésváltás esetén érvényesült, hogy 60 ezer/ha állománysưrûségig a termések szignifikáns mértékben növekedtek, a 80 ezer/ha tőszám esetén már nem tapasztaltunk szignifikáns mértékú termésnövekedést.

A tôszám egyik vetésváltási modell esetén sem mutatott összefüggést egyik agronómiai tulajdonsággal sem. Ezzel szemben a trágyázás erôs vagy közepes pozitív kapcsolatot adott a kukorica növények magasságával, az üszögfertőzés, a csôfuzárium-fertőzés-, és a szárdőlés mértékével, valamint a Push-teszt értékével és a termés nagyságával.

\section{IRODALOM}

Berzsenyi Z.-Dang, Q. L.: 2006. A növényszám hatásának vizsgálata különböző tenyészidejű kukorica- (Zea mays L.) hibridek vegetatív és reproduktív szerveinek növekedésére Richards-függvénnyel. Növénytermelés. 55. 3-4: 255-275.

Clements, J. M.-Campbell, W. K.-Maragos, M. C.-Pilcher, C.-Headrick, M. J.-Pataky, K. J.-White, G. H.: 2003. Influence of Cryl Ab protein and hybrid genotype on Fumonisin contamination and Fusarium ear rot of corn. Crop Science. 43: 1283-1293. 
Debreczeni B.-né-Szlovák S.: 1985. A kukorica N-felvételének a tanulmányozása 15-N jelzett mútrágyával. III. Magyar Növényvédelmi Kongresszus. Szeged. 7. 2-4: 11. Győrffy B.: 1976. A kukorica termésére ható növénytermesztési tényezők értékelése. Agrártudományi Közlemények. 35: 239-266.

Győrffy B.-Berzsenyi Z: 1992. Martonvásári vetésforgó kísérlet 30 éves termésadatának összesítése 1961-1990. MTA Mezőgazdasági Kutatóintézetének és Kísérleti Gazdaságának Közleményei. 16.

Izsáki, Z.: 2005. Limit value of nutritionalstatus of maize (Zea mays L.) for plant analysis. Cereal Res. Comnmun. 33. 1: 101-104.

Kurowski, T. P.-Adamiak, E.: 2007. Occurence of stem base diseases of four cereal species grown in long-term monocultures. Polish Journal of Natural Sciences. 22. 4: 574-583.

Nagy J.-Huzsvai L.: 2005. Hibridválasztás a kukoricatermesztés középpontjában. Gyakorlati Agrofórum Extra. 9: 30-32.

Nagy J.: 2007. Kukoricatermesztés. Akadémiai Kiadó. Budapest.

Pepó P.: 2001. A genotípus és a vetésváltás szerepe a kukorica tápanyagellátásában csernozjom talajon. Növénytermelés. 50. 2-3: 189-202.

Pepó, P.: 2006. Fejlesztési alternatívák a magyar kukoricatermesztésben. Gyakorlati Agrofórum Extra. 13: 7-11.

Pepó P.: 2009. A kukorica (Zea mays L.) termése és növénydôlése száraz és csapadékos évjáratban csernozjom talajon. Növénytermelés. 58. 3: 53-66.

Pepó P.-Tóth Sz.-Bódi Z.: 2006. Kukoricavonalak és hibridjeik Fusarium ssp. és kukoricamoly-(Ostrinia nubilalis Hübner) ellenállóságának vizsgálata diallél keresztezésben. Növénytermelés. 55. 1-2: 63-70.

Sárvári M.-Boros B.: 2010. A vetésváltás és az NPK tápanyagellátás hatása a kukorica termésére. Növénytermelés. 59. 3: 37-52.

A szerzók levelezési címe - Adress of the authors:

Vári Enikő-Dr. Pepó Péter

Debreceni Egyetem AGTC Növénytudományi Intézet

Debrecen

Böszörményi út 138.

H-4032 